Central Washington University ScholarWorks@CWU

2003

\title{
Keeping the citizenry informed: early congressional printing and 21 st century information policy
}

Aimée C. Quinn

Central Washington University, aimee.quinn@cwu.edu

Follow this and additional works at: https://digitalcommons.cwu.edu/libraryfac

Part of the Library and Information Science Commons, and the Other Public Affairs, Public Policy and Public Administration Commons

\section{Recommended Citation}

Quinn, Aimée C., "Keeping the citizenry informed: early congressional printing and 21st century information policy" (2003). Library Scholarship. 69.

https://digitalcommons.cwu.edu/libraryfac/69 


\title{
Keeping the citizenry informed: early congressional printing and $21^{\text {st }}$ century information policy
}

\author{
Aimée C. Quinn* \\ Richard J. Daley Library, University of Illinois at Chicago, 801 S. Morgan m/c 234, \\ Chicago, IL 60607-7041, USA
}

\begin{abstract}
Although the electronic revolution in publishing fostered a new Information Age, the need for government documents in tangible format continues. This paper examines the historical roots of congressional printing compared to $21^{\text {st }}$ century challenges to information policy. The author argues that the founding fathers intentionally did not include language mandating the printing of government information, aside from the Journal as described in the Constitution, for the simple reason that they viewed it as an inherent obligation on the part of all elected officials. As such, restrictive information policies, such as the U.S.A. Patriot Act, impinge upon the original intent of the founding fathers and indeed, threaten the ideal of a democratic society. () 2003 Elsevier Inc. All rights reserved.
\end{abstract}

\section{Introduction}

In the 35 years between the law that created the Government Printing Office ${ }^{1}$ and the first governmentwide printing and binding law, ${ }^{2}$ a schism developed where the President assumed more responsibility for the general management of information (collecting, analyzing, and reporting) while Congress held budgetary control over the printing and publication of this information. The codification of these two laws (popularly known as 44 USC ch. 19) centralized government printing and publishing and created the Federal Depository Library Program (FDLP) as a mechanism to ensure the public's right to know ${ }^{3}$; it also defined the politics of government information management in ways that continue to have profound, and in many respects, negative implications for information policy today. Until passage of the

* Corresponding author. Tel.: +1-312-413-0048; fax: +1-330-413-0424.

E-mail address: aquinn@uic.edu (A.C. Quinn). 
U.S.A. Patriot Act, ${ }^{4}$ these earlier laws shaped the management of government information. Now, the U.S.A. Patriot Act poses a greater threat to the spirit of 44 USC ch. 19 than any previous legislation to date. This article examines how the political climate surrounding the formation of public printing in the United States parallels today's challenges in electronic public printing. Key issues for the $21^{\text {st }}$ century are compared against the lessons learned from our shared history. For purposes of this article, there is no delineation between formal printing and publishing by the government. A chart of key legislation and relevant executive orders is included as an appendix to this article.

A basic tenant of citizenship is ready access to information about the issues at hand, not just for the moment, but as a permanent record available for citizens and scholars to reflect upon indefinitely, which then become evidence for the future to connect with the past. In other words, there needs to be community memory in addition to the public record of our government to record true democracy in action. The Patriot Act, coupled with the E-Government Act of 2002, ${ }^{5}$ underscores one of the longest battles in the history of the U.S. government-the control of information. The outcome of this battle shapes community memory. Much of the problem stems from the uneasy balance of power established in the Constitution. This document authorizes Congress to manage the budget, the President to make policy, and the Judiciary to define the law; all three share responsibility to make law whether through legislation, executive order, or interpretation leading to precedent. However, while these three branches govern, the entire structure of American government rests on the final interpreter of the Constitution, the people of the United States. ${ }^{6}$

An illustration of this uneasy balance is an examination of the political climate surrounding the federal printing laws beginning in the third Congress compared to the climate of $21 \mathrm{st}$ information. An interesting note is the courts have stayed out of this power struggle for the most part. When the founding fathers envisioned their ideal government, it was with the notion that citizens, like themselves, would determine the course of the new nation. As part of this vision, free and easy access to information was a basic tenet. One of the reasons articulated for revolt against the English monarchy was:

He has called together legislative bodies at places unusual, uncomfortable, and distant from the depository of their public Records, for the sole purpose of fatiguing them into compliance with his measures

\section{Declaration of Independence}

http://memory.loc.gov/const/declar.html

Thomas Jefferson argued in support of legislative bodies be physically near their public records, which may imply that for the people to govern, they to would need to have access their public records. Indeed after decades of voluntary publication of the laws and congressional actions by cooperating newspapers, the notion of a depository of public record is one of the underlying principles in the development of the FDLP. A fundamental flaw in giving newspaper publishers sole responsibility for disseminating government information is that their goal was to sell their product, not foster democracy or create community memory. This need is not lessened by the electronic format of modern information dissemination. 


\section{Historical printing}

The idea of public information was a radical concept at the time of the American Revolution. The traditions of public printing in England had not crossed the oceans to the colonies except to a few exceptional people. In fact, the concept of a colony revolting and creating their own sovereign nation had never been done before, thus the decisions facing the new government appeared insurmountable. Nonetheless the issue of public printing is one of the most trifling, yet essential, challenges for the new government. In the classic tome, The Books of a New Nation, Powell noted:

The problems of government printing and publishing...were essential matters. Without publishing, the government could not proceed, nor could it record what it had done. And if our minikins and molecules of bibliography shed only oblique lights on big affairs, still it is worth remarking that the event they briefly illuminate is the building of a nation. ${ }^{7}$

Printing was still a relatively new phenomenon in 1774, of which only the well-to-do could avail themselves since they had both the education to be able to read, and the wealth to purchase the books. According to scholars of early Anglo American book trade, little research has been conducted into what the colonists were reading or even purchasing from book dealers in London. ${ }^{8}$ Printed materials available in the colonies at the time of the American experiment were related primarily to religious texts and newspapers. Indeed, any records we have related to the founding of our government is due to the reporters and publishers of newspapers. The Continental Congress, while discussing the need for making certain laws public, was constantly short of funds to pay to have any printing completed. The first book of fiction published in the United States was in $1789 .{ }^{9}$ Although the printing press had been around for more than two hundred-fifty years, printing by a government was a relatively new concept. Society expected laws and warrants to be printed, but the daily proceedings of a government were considered to be private. ${ }^{10}$ The Continental Congress, comprised of learned men, farmers, merchants, and tradesmen, understood the importance and value of the printed word made public; yet the Congress kept secret journals in order to protect the new country from her enemies. These secret journals were not released to the public until the $19^{\text {th }}$ century. ${ }^{11}$

The first printing act was signed into law March 3, 1795, 19 years after the government of the United States of America was established and six years after the Constitution was ratified. Entitled An act for the more general promulgation of the laws of the United States (1 Stat. 443, Ch. 50, 1795), this law was published in the third Congress, so what happened to the laws from the first two Congresses? According to the Preface of the United States Statutes at Large, Congress authorized the printing of these laws in 1845 as part of this first three-volume set of public laws with the intention of an annual publication of the laws. The basis for a true democracy is that every citizen in the democracy is an equal voice. ${ }^{12}$ This concept is dictated by equitable education, understanding, and access to information. For centuries, scholars have studied the laws and writings of the great leaders of civilization hoping to shed light on why this simple maxim is so difficult to achieve. Factors such as reading ability, comprehension, and access to information create barriers to democracy, yet these factors are inherent to our society and to humanity in general. Race, economy, and geography also create barriers in this equation. If person $\mathrm{X}$ has the wealth to obtain the 
information plus the ability to comprehend this information or has the drive to find the information plus the ability to understand it, person $\mathrm{X}$ would be the kind of person the forefathers hoped to be the ideal citizen. However, in revolutionary America, only rich (educated) white men could be citizens. Women, children, and minorities were all property, thus could not be citizens. Missing from this equation is intellectual curiosity, the personal desire to learn. Without this curiosity, the truth of democracy must be elusive. The framers of the United States were on fairly equal footing when it came to reading and writing. Although some of the delegates had a university education while others did not, they had the common denominator of education. The printed word is vital to any person wishing to participate in government.

What constitutes government printing in early America is debatable. Should currency be counted as a form of early government printing? Powell counts both currency and the Great Seal of America as an example of early U.S. printing. In the history of our nation, the idea of the government as a publisher was a side effect to the need to build strong support for revolution. The ins-and-outs of the printing world during this period are chronicled in several studies including Isaiah Thomas's seminal piece, The History of Printing in America, which includes references to the few items published by the government. Even bibliographers of American History rarely include government documents in their compilations. The Constitution provided for the publication of the House and Senate journals, but not for any other regular publication like judicial decisions, executive reports, or even statutes. Later Congresses had to go back and order laws from its early sessions be printed, because the members assumed that the laws would be made available, yet no provision to ensure this was made in either the Articles of Confederation or later, the Constitution of the United States. Article I, Section 7 of the Constitution requires that the votes of all laws plus objections to the bill be entered in the Journal. This requirement does not necessarily allow that the bill itself will be recorded in its entirety in any form (as introduced to enrollment). During the Constitutional debates, Judge James Wilson, delegate from Pennsylvania, eloquently spoke of the need for printing all nonsecret proceedings on a regular basis so the pubic could have an accurate understanding of what the nation was doing. ${ }^{13}$ Yet, he too did not offer laws or language in the Constitution requiring the printing of government information. In fact, the opposition to Wilson's views was mainly due to the need for secrecy related to military affairs and trade, not to the idea of printing. This view rings true today given the current climate of not releasing information as a means of ensuring national security.

\section{Scholars views}

With the lack of precedent for publishing government information, scholars note the gap in historical research from this period. Shiflett argues for the need to research the entire fabric of early American publishing while Childs, Friedenwald and Schmeckebier try to unravel the practices of printing the Journals. All examine segments of the printing history, but a comprehensive review of the diaries, papers, newspaper accounts, speeches and letters of the members of the Continental Congress and the various state legislative bodies determining their policies on independence to the ratification of the Constitution has yet to be accom- 
plished. The Congress of the United States still has not published for its citizens a comprehensive history of this nation's legislation. Granted the Serial Set and Congressional Record (with their earlier titles) along with the Journals are a major foundation for this research, yet, a complete picture of the times is not available; nor could it be. The Continental Congress was plagued with many woes ranging from states not sending representatives or providing adequate instruction on issues to those who attended to the lack of funds needed to actually support a central government. ${ }^{14}$

Once the Constitution was drafted, ratified, and implemented, these problems lessened. Taxes were levied and the former colonies began to participate more actively in the new central government. According to Tinling, the first year of the new government, Congress "established a system of revenue making the national government financially independent of the states and thereby made it possible to pay off the debt accumulated during the Revolution and the years of the financially incapable Continental Congress. It created a federal judiciary. It provided for diplomatic representation in foreign countries, made treaties and regulated trade with Indian tribes, and organized the Western territories... It set up executive departments -State, Treasury and War ... established lighthouses, beacons, buoys, and public piers; and arranged for the first census." With all this work complete, is it any wonder that a comprehensive record of this work was not made? Instead, Congress relied on the shorthand of Thomas Lloyd, a journalist who recorded the first year of Congressional deliberation and published it as the Congressional Register. ${ }^{15}$

One of the biggest problems surrounding the printing of government information after 1789 was the replication of manuscripts. The printers produced numerous versions of everything sent by Charles Thomson, the indefatigable Secretary of the Congress. While the Bradfords are noted as the original government printers, Stathis and Powell show that they were not the only ones favored. Individual members went to other printers to have their copies of marked-up bills printed up so they could send it on to their states for review. While not technically government documents, since they typically were not ordered by Congress to be printed, many were paid for by the state governments. In fact, Congress approved the reprinting of several documents. Since the publication of these documents was not by Congressional order, they are not considered official government publications. The entire question of "official" government information is a twentieth century phenomenon. In the early days of America, Congress was not bothered by the minutia of "official" versus "unofficial". 16

\section{Historical public printing recap}

From 1789 to 1860 , congressional printing was on a case-by-case basis by the specific order of Congress ${ }^{17}$ where quantities were determined by anticipated need. Little thought was given to long-term access or storage of this material, but the Congress argued over the need to publish its proceedings. Congress was plagued with publishers of dubious ethics who were more interested in getting paid, than in fulfilling their contracts. There are several versions of the Journals and even the Serial Set. Because no provisions were made for printing, there also was no provision for retaining an official copy on hand for reprinting. ${ }^{18}$ 
As such, when Congress needed to reprint a report or a bill, they depended upon either the Secretary of the Senate or the Clerk of the House to ensure that the publication was completed. In turn, the Secretary or the Clerk pulled together what they had on hand which was not always exactly the same order of items originally printed. Farrand noted that several copies of the two Congressional Convention printings with notations in the margins were available for publication and he spent years sorting out the versions. ${ }^{19}$

Later, Kerr and Rips document the number of times various congresses addressed the issue of centralized printing. Rips posits the intent of the Printing Act of 1895 was to centralize all government printing but by the time her book was published in 1949, this intent was disregarded. ${ }^{20}$ While the importance of this law cannot be stressed enough, historians, bibliographers, and librarians all acknowledge that it only scratched the surface of problems related to government printing. Amendments to the 1895 laws were put in place including several in the 1960s resulting in an expansion of the Federal Depository Library Program. The 1962 amendments required federal agencies to deposit all materials (except those deemed classified or for internal use only) to the Government Printing Office, but did not include any mechanism to ensure compliance; thus several government agencies do not follow the demands of the Depository Act of 1962 (76 Stat. 352).

The 1968 public printing and documents law (82 Stat. 1238) established the Joint Committee on Printing to oversee the printing and dissemination of federal government information and to provide some measure for compliance. This law tried to overhaul the earlier printing laws and close many of the loopholes created by the 1962 law. Combined, these two laws reinvented the Federal Depository Library Program by broadening the responsibilities of a depository, creating the regional system, and expanding the number of libraries. While the laws intended to make government information more accessible, they overlooked the importance of establishing any kind of enforcement mechanism to ensure that all government information as defined by these laws would in fact be deposited. ${ }^{21}$ In the late twentieth century, electronic information would also become fugitive. (Table 1).

\section{$5.20^{\text {th }}$ century information policy}

As mention above, the Internet revolutionized printing. Not since the invention of the printing press has open communication been so simple, universal, and democratic. The U.S. Congress, along with the Clinton administration, seized upon the new web technology as the means to make government information more accessible; however, new impediments to the printing and dissemination of this information were simultaneously put in place. Using the Internet as a conduit, the supply of government information fostered a growth in the demand by citizens of all ages and educational attainment. ${ }^{22}$ Yet as the demand increased, some members of Congress became fearful over the loss of control in determining what kinds of data and how much government information should be disseminated. Subsequent legislation proved these fears to be largely unsubstantiated, because control could be exerted through legislation and regulation. ${ }^{23}$ A re-examination of the kinds of information produced by the government in the public domain led to a myriad of rules and regulations introduced and passed by the $104^{\text {th }}, 105^{\text {th }}$, and $106^{\text {th }}$ Congresses which ultimately crippled the ability of 
Table 1

Legislative Authority Citations

\begin{tabular}{|c|c|c|}
\hline ISSUE & CITATION & DATES \\
\hline $\begin{array}{l}\text { No constitutional authority for } \\
\text { printing U.S. government } \\
\text { information aside from the } \\
\text { Journals }\end{array}$ & U.S. Constitution & 1789 \\
\hline First public printing law & $\begin{array}{l}3^{\text {rd }} \text { Cong., Sess. II, Ch. } 50 \text { pp. } \\
443\end{array}$ & March 1795 \\
\hline Establishment of the GPO & 12 Stat. 117 & July 1860 \\
\hline Creation of the FDLP & 28 Stat. 1601 & 1895 \\
\hline $\begin{array}{l}\text { Freedom of Information Act } \\
\text { (FOIA) }\end{array}$ & 80 Stat. 250 , P.L. $89-487$ & July 1966 \\
\hline Privacy Act of 1974 & 88 Stat. $1905(b)(1)$; P.L. 93-579 & 1974 \\
\hline $\begin{array}{l}\text { Armstrong v. Executive Office of } \\
\text { the President (Federal Circuit } \\
\text { Court for the District of } \\
\text { Columbia Circuit ruled that } \\
\text { electronic mail and word } \\
\text { processing files must be } \\
\text { managed as government } \\
\text { records) }\end{array}$ & 90 F.3d 553, 557-66 & $\begin{array}{l}\text { August } 1993 \text { (Supreme Court } \\
\text { declined to review this case } \\
\text { in May 1997) }\end{array}$ \\
\hline $\begin{array}{l}1996 \text { FOIA Amendments (called } \\
\text { Electronic Freedom of } \\
\text { Information Act) mandate } \\
\text { publicly accessible "electronic } \\
\text { reading rooms" with agency } \\
\text { FOIA response materials and } \\
\text { other information routinely } \\
\text { available to the public, with } \\
\text { electronic search and indexing } \\
\text { features }\end{array}$ & 110 Stat. 3048 , P.L. 104-231 & October 1996 \\
\hline $\begin{array}{l}\text { E.O. 13231, Critical } \\
\text { Infrastructure in the } \\
\text { Information Age }\end{array}$ & 66 FR 53063 & October 2001 \\
\hline $\begin{array}{l}\text { E.O. 13233, Further } \\
\text { Implementation of the } \\
\text { Presidential Records Act } \\
\text { (retroactive to beginning of } \\
\text { term) }\end{array}$ & 66 FR 56025 & November 2001 \\
\hline USA Patriot Act signed into law & 115 Stat. 271 (P.L. 107-56) & October 2001 \\
\hline $\begin{array}{l}\text { Department of Homeland } \\
\text { Security established }\end{array}$ & 116 Stat. 2135 (P. L. 107-296) & November 2002 \\
\hline $\begin{array}{l}\text { E-Government Act signed into } \\
\text { law }\end{array}$ & P. L.107-347 & December 2002 \\
\hline
\end{tabular}

This chart shows the chronology of legislation and executive orders discussed.

agencies to provide access to all government information. By the beginning of the twentyfirst century, the number of public documents disseminated was drastically reduced. The Library Programs Service at GPO distributed a total of 14,517 tangible products in FY 2001 
(compared to 28,232 in FY 2000 and 44,734 in FY 1995) while simultaneously expanded GPO Access and put into place a permanent public access policy. ${ }^{24}$ This expansion into the electronic frontier enabled citizens to have better access to government information. It is much easier to track legislation, comment upon proposed regulations, and even contact your Congressman.

The Internet is a wonderful medium for providing access to information. It is not a medium for long-term retention of the information. The only proved method of historical research is through the printed word. Electronic information must be migrated as technology advances and expertise using the both the old and new technologies. The Government Printing Office addressed these concerns in their 1996 Report to the Congress: Study To Identify Measures Necessary For A Successful Transition To A More Electronic Federal Depository Library Program. ${ }^{25}$ This report also raises many of the questions articulated in this article without offering any specific answers aside from the politics to keep the GPO alive and well. In the six years since its publication, neither the Executive Branch nor the Legislative Branch have answered the questions related to long-term access to electronic information. Given the current war climate and the growing need for national security, one could infer that as in the past, Congress may think the issue essential, but not important enough to deal with today. One key challenge to continuing the tradition of public printing is the passage of the U.S.A. Patriot Act in October 2001, a sweeping law that gave unprecedented powers to the Attorney General including being able to obtain data on citizens previously considered private such as reading lists and broadly defining computer trespassers. $^{26}$

\section{6. $21^{\text {st }}$ century printing}

The terrible tragedy of September 11, 2001 heightened fears about national security and provided the supporters of limiting public information the opportunity to exert tighter control over the publication of government information. As seen in earlier times, the defense was "national security" while at the same time restricting civil rights. While access to public information is not a civil right per se, it is a fundamental right for any democracy to operate. The U.S.A. Patriot Act lays the foundation for law enforcement to obtain patron records of materials charged-out and Internet logs. In addition, many executive branch agencies removed public information from official websites, popularly called "web-scrubbing" in the wake of the terrorist attacks. "Web-scrubbing" is strengthened by the U.S.A. Patriot Act. ${ }^{27}$ While it is vital for the government to protect her citizens and territory, wholesale removal of public information as a control mechanism is not necessarily the best way to deter terrorist attacks. As examined elsewhere in this article, controlling the flow of information fosters distrust in elected officials and erodes the democratic process. In fact, this control forces further dependence upon community memory as the sole authority rather than as a balance for official records.

Another huge change in public printing was the medium, the Internet. The E-Government Act of 2002 enforces this new medium as the conduit of official dissemination and communication between federal agencies and the public in addition to traditional telecommunica- 
tions. Printing in an electronic medium is not a twenty-first century development. The last decades of the twentieth century witnessed tremendous growth in technologies which were married to publishing. However, modern government information policy tends to focus on what information is not released rather than on the free and open dissemination of information to the public. While information dissemination moves more quickly, it becomes more ephemeral, vanishing not with the slow decay of old paper (or the methodical feeding of sheets into a paper shredder), but by simply deleting the file. Tired old arguments against printing and publishing information have been trotted out for restricting certain information from electronic distribution. "Fugitive documents," which agencies may characterize as "work product" or "internal documents," but later leak to the press are becoming ever more unobtainable for the average citizen. As the depository community try to make the laws more inclusive, the purpose of a public record has gotten lost and community memory becomes distorted. Nowhere is this more visible than in the maze of government web sites. In order to assist citizens navigating the fast-growing Internet, Congress supported the creation of FirstGov, a portal to e-government. According to the Honorable Steven Horn, "FirstGov is an important step in making Government information and services available to the public 7 days a week, $24 \mathrm{hr}$ a day. FirstGov-and electronic government, in general-offer the potential to revolutionize the way citizens and businesses interact with their Government."28 This portal is a good initial step in providing equitable access to government information, but only when the content of the web sites is not being restricted. The list of federal websites where government information has been removed (due to their content) or has been taken down completely since September 11,2001 is disturbing. ${ }^{29}$

The debate over content-rich web sites (such as the Environmental Protection Agency's Preparedness-Emergency Planning and the Community Right to Know ${ }^{30}$ which details chemical hazards in communities) are criticized as blueprints for terrorists seeking targets. The $O M B$ Watcher reported,

[The Chemical Manufacturing] Industry became quite concerned over the fact that the worst case scenarios would have information about death and injuries that could be caused by company accidents. To avoid disclosure, the industry raised concerns about terrorism if information were made available through the Internet. They were able to get the FBI to weigh in with concerns about terrorism even though there was no evidence of such concerns|.|.|. In the aftermath of the September 11 attack, we must balance the benefits of public access in our democratic society with the necessary steps to make certain our lives are secure. The simplest solutions are always to cut back on the public's right-to-know. But we believe this would be very dangerous. During the RMP debates, OMB Watch argued that public disclosure would spur industries to reduce chemical hazards, and pointed out that there is otherwise no program to require industries to even conduct a review of inherently safer options. ${ }^{31}$

Later, on November 1, 2001 President George W. Bush signed Executive Order 13233 expanding Presidential authority for determining the disposition of executive papers, including work product, scheduled for release to the public. This Executive Order gives extraordinary powers to the President regarding the use executive privilege over public documents. Congress is still examining the ramifications of this new order through the introduction of legislation and has held one hearing thus far on the issue. ${ }^{32}$ 
While this Executive Order is limited to Presidential/Vice-Presidential correspondence, it is conceivable that executive privilege may extend to agency publications if the President determined that the "work product" from an agency required special consideration. In fact, there is some precedent for extending this privilege to selected agencies. In his testimony before Congress, Professor Mark Rozell noted:

During the Watergate scandal former president Richard Nixon claimed that executive privilege was a power that belonged to the entire executive branch of the government and that it was not subject to any limits. ${ }^{33}$

This comment has chilling implications for the future of public government information especially in times of war or when national security has been compromised. Congressional action in regard to this executive order remains to be seen, but the potential impact on information policy is clear. The power struggle between the Executive and Legislative branches is being redrawn in an all too-familiar ground.

\section{Key issues for the $21^{\text {st }}$ century}

So what does this examination of printing history teach us today? Publication of government information is at a cross-roads. The advent of the Internet and the move toward a national information infrastructure enables the everyday citizen to communicate with their representatives easier than before and makes it easier to remove information. The 2000 presidential election witnessed the first transition of public information on the Internet between administrations. Indeed, the beginning of the century saw a basic cleansing of the old administrative web sites to make way for new sites reflecting the President Bush's views; many of the Clinton-era sites were not archived or saved anywhere resulting in a loss of electronic information. This same trend happened with changes in Congressional delegations, new appointments to the Judiciary and even trickled down to the states and local governments. A futile attempt to take snapshots of the sites was made by National Archives; it was too little, too late. ${ }^{34}$ This legacy set the stage for the new administration's attempts to control information. In the first two years of his administration, President Bush signed E.O. 13231, Critical Infrastructure in the Information Age, on October 16, 2001 which exerts executive control over the security of disruption of the operation of information systems for critical infrastructure; ordered the Secretaries of Agriculture and Health \& Human Services along with the Administrator of the EPA to have the authority to classify information as secret; ${ }^{35}$ signed E.O. 13233 extending executive privilege as discussed above; and supported Attorney General Ashcroft's memorandum to use "a sound legal basis" 36 in determining release of information under FOIA. As these executive actions are heralded as the basis for national security, they lay the framework for a less open government guided by principles of secrecy rather than by openness. A result of this practice is heightened tensions between Congress and the Executive Branch especially over the release of information as related to national security. ${ }^{37}$ These tensions echo Judge Wilson's plea for publishing the laws during the Constitutional Convention. While President Bush harkens back to the Founders intent, it appears he hasn't learned that keeping the citizenry informed is essential to the basic 
democratic process. If knowledge is power (or so the American Library Association claims), then the balance of power between the three branches of government and the people remains undecided. Indeed, the Hon. Ron Lewis, representative from Kentucky noted:

As I understand it, the debate before us today is one about power. Not power in the raw political sense, but in terms of the allocation of government authority between each branch of government- or more specifically, between Congress and the Judiciary. In a federal system that relies on checks and balances between the three branches to protect our liberty, having this debate is fundamental to understanding what kind of government we have, or more important, aspire to. Indeed, it is a debate and conversation that has been taking place since our founding. ${ }^{38}$

\section{Notes}

1. Joint Resolution in Relation to the Public Printing (12 Stat. 117, 1860).

2. An Act Providing for the Public Printing and Binding and the Distribution of Public Documents (28 Stat. 601, 1895)

3. While this law did not perfect the dissemination of government information, many unsatisfactory practices such as overcharging for duplicative work and the amount of waste were reduced through the centralization of printing.

4. 115 Stat. 271 (P.L. 107-56)

5. P.L. 107-347 signed into effect December 17, 2002.

6. Congress, the Court, and the Constitution: hearing before the Subcommittee on the Constitution of the Committee on the Judiciary, House Of Representatives, One Hundred Fifth Congress, Second Session, January 29, 1998 p. 23. Available at: http://commdocs.house.gov/committees/judiciary/hju58804.000/hju58804_0.htm

7. Powell, J. H. The Books of a New Nation: United States Government publications, 1774-1814. Philadelphia, University of Pennsylvania Press, c1957, p. 61.

8. Botein, Stephen. The Anglo American Book Trade before 1776 in Printing and Society in Early America. pp. 48-50.

9. Winterich, John T. Early American Books \& Printing. New York: Houghton Mifflin Company; Cambridge: The Riverside Press, 1935, p. 150.

10. English common law established the precedent of legal publication but the actual investigation as to the requirement of what was published and disseminated to the public has yet to be explored. Blackstone's Commentaries do not discuss publishing to printing of laws; instead, these acts are considered common law.

11. Friedenwald, Herbert. "The Journals and Papers of the Continental Congress" Annual Report of the American Historical Association for the Year 1896, volume 1. Washington: Government Printing Office, 1897. Published in serial set volume 3550, volume 1 , ch. 5 , p. 9.

12. In Federalist Paper No. 10, James Madison writes "There are again two methods of removing the causes of faction: the one, by destroying the liberty which is essential to its existence; the other, by giving to every citizen the same opinions, the same passions, and the same interests" which assumes the same ability to gather the 
information to form an opinion. Available at: http://memory.loc.gov/const/fed/ fed_10.html

13. Elliot, Jonathan. The debates in the several state conventions on the adoption of the federal Constitution as recommended by the general convention at Philadelphia, in 1787. Together with the Journal of the federal convention, Luther Martin's letter, Yates's minutes, Congressional opinions, Virginia and Kentucky resolutions of '98'99, and other illustrations of the Constitution, second edition. Washington: Printed for the Editor, Published under the Sanction of Congress, 1836, vol. 1, Saturday, August 11, 1787, p. 408.

14. Burnett, Edmund Cody. The Continental Congress: a definitive history of the Continental Congress from its inception in 1774 to March, 1789. New York: W. W. Norton \& Co., 1941, p. 526-534.

15. Tinling, Marion. "Thomas Lloyd's Reports of the First Federal Congress", William and Mary Quarterly, third series, 18:4 (Oct. 1961), pp. 519-545., p. 519.

16. Powell, J. H. The Books of a New Nation: United States Government publications, 1774-1814. Philadelphia, University of Pennsylvania Press, c1957, p. 35-36.

17. Stathis explores how the publishers took advantage of Congress as witnessed by the number of times Congress changed publishers in the eighteenth century in "The Evolution of Government Printing and Publishing in America", Government Publications Review 7A (1980), pp. 377-390. p. 378-380.

18. The Library of Congress was founded in 1800. Its collection was based upon the library of Thomas Jefferson. Available at: http://www.loc.gov/loc/legacy/ preface.html

19. Powell, J. H. The Books of a New Nation: United States Government publications, 1774-1814. Philadelphia, University of Pennsylvania Press, c1957, p. 63.

20. Boyd, Anne Morris. United States Government Publications, Third edition, revised by Rae Elizabeth Rips. New York: H. W. Wilson, Co., 1949., p. 25.

21. Shiflett, Orvin Lee. "The Government as Publisher: An Historical Review", Library Research 4 (Summer 1982), pp. 115-135, p. 118.

22. Taken from a speech given by Mr. Francis J. Buckley, Superintendent of Documents, U.S. Government Printing Office before the National Federation of Abstracting and Indexing Societies February 21, 2000 Philadelphia, PA and reproduced in Administrative Notes 21 (March 2000): 5

23. See $O M B$ Circular A-130, revised November 30, 2000. Available at: http://www. whitehouse.gov/omb/circulars/a130/a130trans4.html

24. Library Programs Service Annual Report,FY 1995 http://www.access.gpo.gov/su_docs/ fdlp/pubs/adnotes/ad111596.html, FY 2000 http://www.access.gpo.gov/su_docs/fdlp/ pubs/adnotes/ad101500.html\#1, FY 2001 http://www.access.gpo.gov/su_docs/fdlp/ pubs/adnotes/ad101501.html\#10.

25. http://www.access.gpo.gov/su_docs/fdlp/pubs/study/studyhtm.html

26. http://www.ala.org/Content/NavigationMenu/Our_Association/Offices/ALA_Washington/ Issues2/Civil_Liberties,_Intellectual_Freedom,_Privacy/The_U.S.A._Patriot_Act_ and_Libraries/Default2437.htm

27. The Education Committee of the Government Documents Round Table compiled a 
chronology of materials removed from government web sites. It is available at: http://www2.library.unr.edu/dept/bgic/Duncan/PPBmillerchronchart.doc

28. Opening statement of Stephen Horn, Chairman, Subcommittee on Government Management, Information, and Technology of the Committee on Government Reform, U.S. House of Representatives at a hearing on FirstGov.gov: Is it a Good Idea? Available at: http://www.house.gov/reform/gmit/hearings/2000hearings/ 001002.FirstGov/001002sh.htm

29. Available at: http://www.ombwatch.org/info/2001/access.html

30. Available at: http://www.epa.gov/swercepp/crtk.html

31. "DOJ Must Complete Its Chemical Plant Site Security Study," OMB Watcher, Vol. 2 No. 19, Sept. 17, 2001. Available at: http://www.ombwatch.org/ombwatcher/ ombw20010917.html\#chm

32. Subcommittee on Government Management, Information, and Technology of the Committee on Government Reform, U.S. House of Representatives. Oversight hearing on the "Presidential Records Act of 1978" Available at: http://www.house.gov/ reform/gefmir/hearings/2001hearings/1106_presidential_records/1106_witnesses. htm; H. R. 4187 The Presidential Records Act Amendment of 2002 was introduced in the House 4/11/2002 and includes a provision to nullify this executive order. On 10/9/2002, the Government Reform Committee ordered it to be reported.

33. Testimony of Mark J. Rozell, Professor of Politics, Catholic University. Available at: http://www.house.gov/reform/gefmir/hearings/2001hearings/1106_presidential_ records/rozell.doc, p. 2.

34. Sprehe, J. Timothy. "Federal Web sites: half-cocked snapshots" Federal Computer Week, February 5, 2001. Available at: http://www.fcw.com/fcw/articles/2001/0205/ pol-sprehe-02-05-01.asp

35. Federal Register v. 66, no. 239 (December 12, 2001) pp. 64345-64347; v. 67, no. 90 (May 9, 2002), p. 31109; 67, no. 189 (September 30, 2002) pp. 61463-61465.

36. Available at: http://www.usdoj.gov/oip/foiapost/2001foiapost19.htm

37. See White House memo to Attorney General at: http://www.whitehouse.gov/news/ releases/2001/12/20011213-1.html

38. Congress, the Court, and the Constitution: hearing before the Subcommittee on the Constitution of the Committee on the Judiciary, House of Representatives, One Hundred Fifth Congress, Second Session, January 29, 1998 p. 5. Available at: http://commdocs.house.gov/committees/judiciary/hju58804.000/hju58804_0.htm 